\title{
Factors of Design Errors in Construction Project (A Review)
}

\author{
Dedy Farhan Fuadie ${ }^{1}$, Yani Rahmawati ${ }^{1}$, Christiono Utomo ${ }^{1}$ \\ ${ }^{1}$ Institut Teknologi Sepuluh Nopember \\ dedy.fuadie15@mhs.mmt.its.ac.id; yanirahmawati@mb.its.ac.id
}

\begin{abstract}
Design is an important step in construction project. Errors in design cause failure in construction stage as well as the project development. Misunderstandings of design concept between parties lead to design errors that able to decrease the quality of construction works, and also cause cost overruns and project delays. Design errors also contribute to engineering failures, which can result in accidents and loss of life. Preventive actions in reducing the errors are necessary. In accordance with these issues, this research is conducted with main purpose to identify the causal factors of design error. Review to previous studies with main topic of design error was taken in order to identify the causal factors. The factors were then validated in an oil and gas industry through observation in design process and also interview to parties whom have experiences in design process. Based from research, it is found that there are 5 main causal factors. The factors are man, method, material, machine, and environment. There are also several factors that are less in accordance with the conditions in the field such as cognitive dissonance, competitive tendering, and adversarial attitudes. By knowing the cause of the design error, can be done to prevent the effort of guarantee project sustainability.
\end{abstract}

Keywords—design error, construction project, oil and gas.

\section{INTRODUCTION}

$\mathrm{D}$ esign can be defined as a roadmap or strategic approach for a person to achieve unique expectations. The design defines the specifications, plans, parameters, costs, activities, processes and how and what should be done within the legal, political, social, environmental, safety and economic constraints in achieving that objective [1].

Project life cycle is a series of project stages starting from initiation to closure [2]. In the project life cycle there is a phase in which the design process is performed. In Figure 1, it can be seen that the design process consist of planning phase, concept design phase and detailed design phase. In the planning phase, the design process is called the design brief. Planning phase is more related to financial modelling and business plan. Therefor the design is only delivered briefly. In the conceptual design phase, the design team is formed. Design team do the design process with design management. At this stage the design has been described more broadly and deeply. The dimension and capacity of a facility are determined in this phase as well. In the detailed design phase, the design has been expressed in the form of images with a detailed description. This drawing is used as a reference for the construction process.

To better understand the design process in a project, the following stages of the design process are presented in Figure 2:

1. Feasibility

In the first stage, a small commission is formed to investigate whether a location can accommodate the desired function or purpose. The result is usually a report that shows how to achieve the goal or modified in the presence of certain limitations. If the report points out that the project is feasible, the project can be implemented.

2. Tender

The selection of design consultants is done competitively.

3. Briefing

Briefing is done between the client and the design consultant. Briefing is important to make efforts to find relevant solutions in fulfilling the client's needs. In general, it is also delivered in written. The main content of briefing is client's needs that have to be achieved.

4. Concept

The design concept is the creative process of making or embodiment of the client's directions and designing the appropriate design responses. Analyses of designs alternatives before final design are determined. The design concept is usually less detailed for a plan but simply allows the client to determine whether the design is appropriate.

5. Scheme

The design scheme is an approved design concept including major decisions in layout, engineering and material engineering. Functions, shapes and economic aspects are determined to be made in more detail [14].

The quality of planning and design is a major factor in the success of a project [3]. The design also covers every aspect of the construction process including operational and maintenance. The design combines the specifications to guide the contractor in developing the means and methods of construction [4].

Errors are deviations from true values, lack of precision, measurement variations due to lack of human 
perfection and tools [5]. There are three types of errors: imperfection, incompatibility, and neglect [4]. Suther [4] mentioned that the imperfection is a deviation on the details that have no effect on construction and facilities. Only minor repairs are required or can be considered acceptable conditions. It does not require additional cost and time. Generally this error is not recorded; it can also be a note on as built drawings for future knowledge. Simply design error can be interpreted as a deviation from planning and specification.

The impacts that often occur due to the weakness of the design are unutilized facilities, addendum contract (cost) that exceeds the original budget, the additional projects for the completion of a project, and also the delay in project execution time. Further impact of the problem is that the business process is hampered and the output of the investment cannot be used properly. In addition, previous studies also mention the effects of design errors [6-10]. Design errors can significantly degrade the project performance by generating reworks, requiring additional time and resource expenditure [6].

Based on previous research there are some impacts resulting from design errors. Designers, who do not have extensive knowledge, can produce incorrect design that produces poor quality work that leads the project to exaggerate its cost and time [7]. It turns design errors into project failure. Design errors also contribute significantly to the incremental cost and timeframe of social infrastructure projects and lead to engineering failure, which can lead to accidents and loss of life [8]. Design errors likewise have become causal root of many accidents that have resulted in deaths and injuries from workers and community members [9]. Furthermore, design errors may contribute to the engineering and

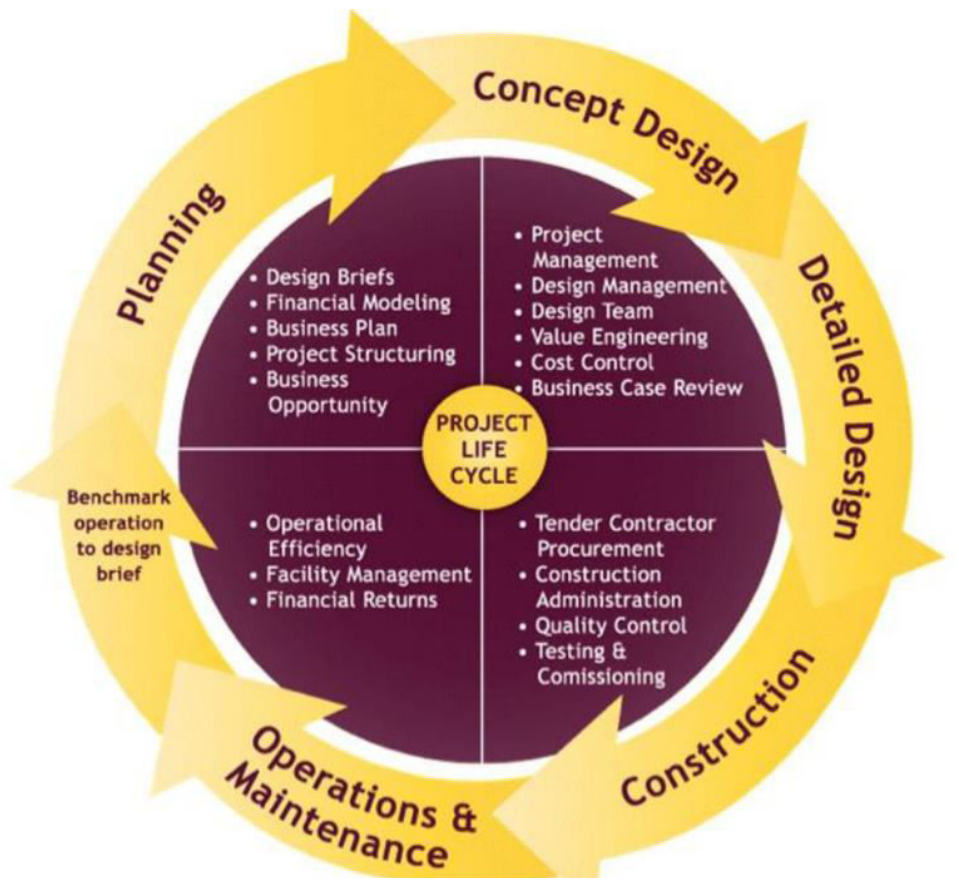

Figure 1. Project Life Cycle [13]

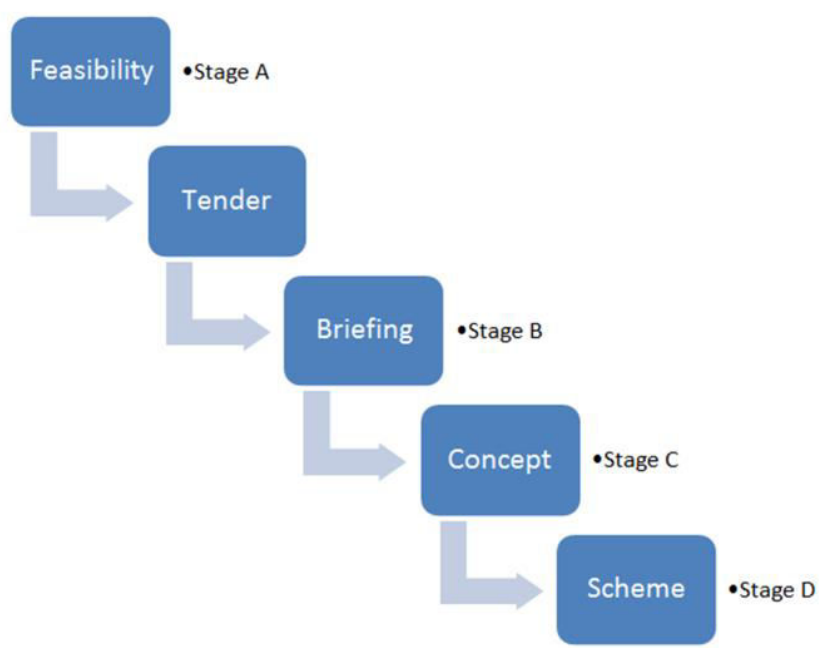

Figure 2. Flowchart of the stage of the design process [14]. 
reliability issues of industrial machine operators, which have been found to have an impact on safety as well [10]. In accordance with this issues, authors conducted research with main purpose to identify the causal factors of design error.

\section{RESEARCH METHODOLOGY}

This research is an explorative research. An exploratory research is a valuable means of finding out 'what is happening; to seek new insights; to ask questions and to assess phenomena in a new light' [11]. To determine factors that are causing the design error, authors conducted literature study and also observation and interview. Review to previous studies with main topic of design error was taken in order to identify the causal factors. The factors were then validated in an oil and gas industry through observation and interviews.

\section{RESULTS AND DISCUSSION}

Based from review literature study related to the topic of design error, found some issues. Han et al [6] built a dynamic system to estimate the negative impact of design errors. Knowledge management and the decision support for design process [15-17]. Love et al [8], analyze the design errors and prevention efforts. The impact of design failure to construction process [18]. Love et al [12] examines how rework and why reworks are caused by design errors in commercial construction projects. Walker [7] examines the aspects of learning in design. Collaboration in design is needed [19]. Lopez et al [9] classified the nature of design errors, causation of design errors and prevention efforts in construction projects. Beside the construction process, the design failures also contributes to failure in project development as well as sustainability of project development [20-21]. In general, from previous several studies there are equations that analyze the causes of design errors, analyze the impact of design errors and efforts to prevent design errors. The differences lay on focus on rework, the use dynamic systems and a focus on the process of learning design.

Based from literature study, it is found that there are 30 causal factors of design errors. The result is presented in Table 1. The results were then validated through observation and interviews to parties who have experience in design process by comparing the variables derived from the previous study and the experiences of respondents are presented in Table 2. Practically the respondents usually use a fishbone diagram to determine the causal factors and classify them in $4 \mathrm{M} 1 \mathrm{E}$ (man, method, material, machine, and environment). In general these variables are in accordance with the conditions in the field or in design process practices at oil and gas project, but there are some variables that according to researchers is less in accordance with the conditions in field, such as:

1. Cognitive dissonance.

This variable has not been found in the field.

2. Competitive tendering.

Logically should be competitive tender will make the participants give the best idea for the design, but may be because the price competition is sacrificed is the design aspect.

3. Adversarial attitudes.

This variable has not been found in the field.

Table 1. Design Error Causal Variables (Adopted from [7], [8], [12])

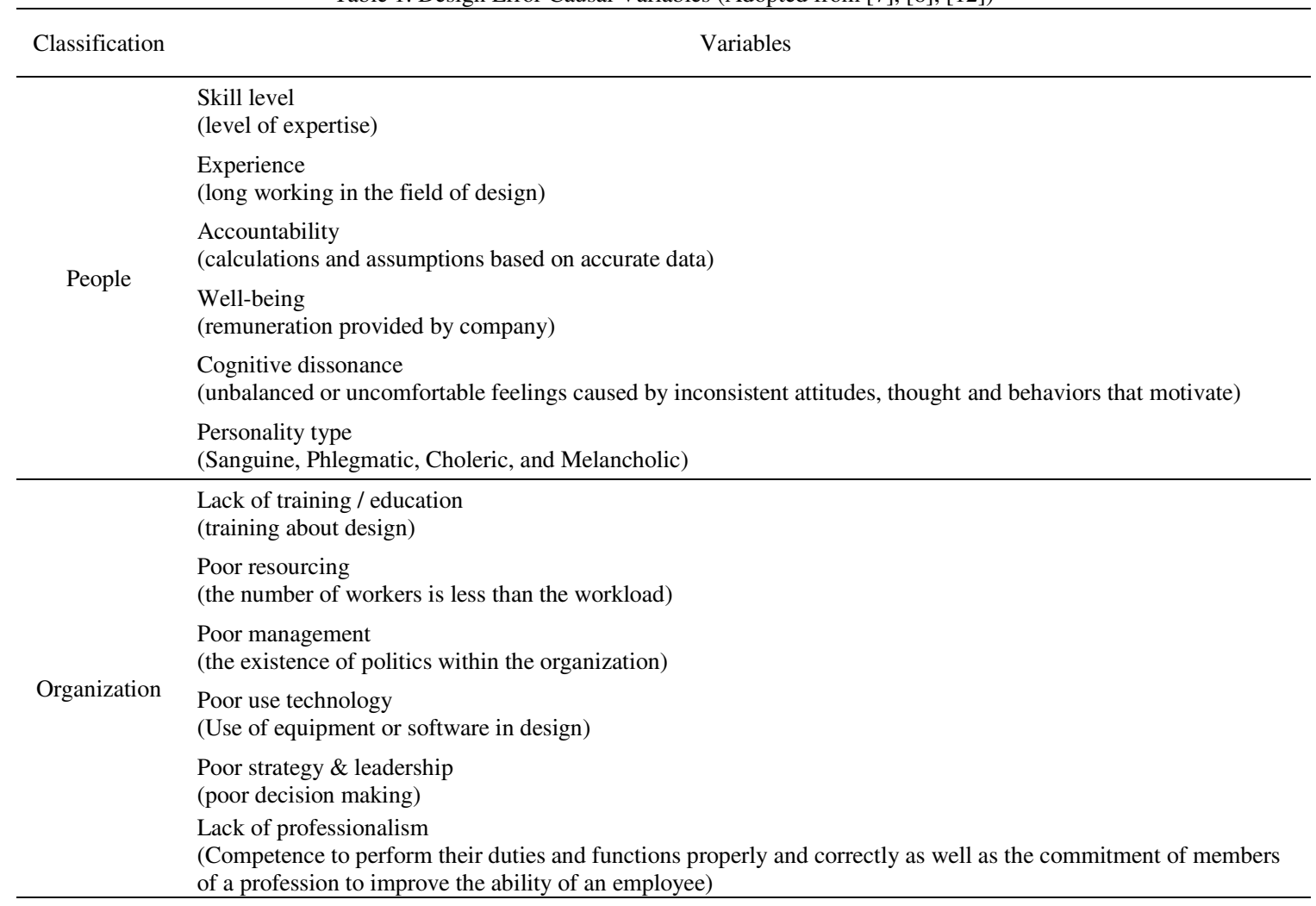


Table 1. Design Error Causal Variables (continued)

\begin{tabular}{|c|c|}
\hline Classification & Variables \\
\hline \multirow{6}{*}{ Project } & $\begin{array}{l}\text { Poor project governance } \\
\text { (project implementation is done badly) }\end{array}$ \\
\hline & $\begin{array}{l}\text { Poor scope definition } \\
\text { (the scope of work is not written clearly) }\end{array}$ \\
\hline & $\begin{array}{l}\text { Traditional procurement } \\
\text { (procurement system with separate stages between design and construction) }\end{array}$ \\
\hline & $\begin{array}{l}\text { Competitive tendering } \\
\text { (tendering is done competitively) }\end{array}$ \\
\hline & $\begin{array}{l}\text { Adversarial attitudes } \\
\text { (conflict or dropping each other) }\end{array}$ \\
\hline & $\begin{array}{l}\text { Poor design integration } \\
\text { (the design does not reflect the whole aspect of it) }\end{array}$ \\
\hline \multirow{5}{*}{$\begin{array}{l}\text { Learning in } \\
\text { design }\end{array}$} & $\begin{array}{l}\text { Group learning } \\
\text { (lack of learning at the team or function level) }\end{array}$ \\
\hline & $\begin{array}{l}\text { Individual learning and sharing } \\
\text { (lack of learning in each individual) }\end{array}$ \\
\hline & $\begin{array}{l}\text { Absorptive capability } \\
\text { (lack of understanding and learning outcomes) }\end{array}$ \\
\hline & $\begin{array}{l}\text { Personal relationship } \\
\text { (communication in the design process is less effective) }\end{array}$ \\
\hline & $\begin{array}{l}\text { Characteristics of knowledge source } \\
\text { (knowledge or lesson learn difficult to access) }\end{array}$ \\
\hline \multirow{5}{*}{ Other aspects } & $\begin{array}{l}\text { Client and End-User Requirements } \\
\text { (the design follows the user's request) }\end{array}$ \\
\hline & $\begin{array}{l}\text { Schedule Pressure } \\
\text { (Design completion time is narrow) }\end{array}$ \\
\hline & $\begin{array}{l}\text { Design Fees } \\
\text { (costs needed in the design process) }\end{array}$ \\
\hline & $\begin{array}{l}\text { Planning During Design } \\
\text { (Less mature planning) }\end{array}$ \\
\hline & $\begin{array}{l}\text { Design Checks, Audits, and Reviews } \\
\text { (no checks, audits, and evaluations were performed on the design results) }\end{array}$ \\
\hline
\end{tabular}

From the observation and interviews, there are some new variables that do not exist in the reference journal i.e.: lack of as built drawings, lack of existing data, and poor master plan definition.

\section{CONCLUSION}

It can be concluded that the causal factor of design error obtained from previous studies generally corresponds to the conditions in the field. There are some variables that according to researchers is less in accordance with the conditions in field, such as cognitive dissonance, competitive tendering, and also adversarial attitudes. There are some new variables that do not exist in the reference journal i.e.: lack of as built drawings, lack of existing data, and poor master plan definition. 
Table 2. Design Error Causal Variables - validated in oil and gas industry (Pertamina)

\begin{tabular}{|c|c|c|c|c|}
\hline Man & Method & Material & Machine & Environment \\
\hline Skill level & $\begin{array}{l}\text { Lack of training } \\
\text { / education }\end{array}$ & $\begin{array}{l}\text { Characteristics } \\
\text { of knowledge } \\
\text { source }\end{array}$ & $\begin{array}{l}\text { Poor use } \\
\text { technology }\end{array}$ & $\begin{array}{l}\text { Adversariat } \\
\text { attitudes }\end{array}$ \\
\hline Experience & Poor resourcing & $\begin{array}{l}\text { Lack of as built } \\
\text { drawings }\end{array}$ & & $\begin{array}{l}\text { Learning and } \\
\text { cultural } \\
\text { organizational } \\
\text { support }\end{array}$ \\
\hline Accountability & $\begin{array}{l}\text { Poor } \\
\text { management }\end{array}$ & $\begin{array}{l}\text { Lack of } \\
\text { existing data }\end{array}$ & & Group learning \\
\hline Well-being & $\begin{array}{l}\text { Poor strategy \& } \\
\text { leadership }\end{array}$ & $\begin{array}{l}\text { Poor master } \\
\text { plan definition }\end{array}$ & & $\begin{array}{l}\text { Individual } \\
\text { learning and } \\
\text { sharing } \\
\end{array}$ \\
\hline $\begin{array}{l}\text { Cognitive } \\
\text { dissonance }\end{array}$ & $\begin{array}{l}\text { Lack of } \\
\text { professionalism }\end{array}$ & & & $\begin{array}{l}\text { Schedule } \\
\text { Pressure }\end{array}$ \\
\hline Personality type & $\begin{array}{l}\text { Poor project } \\
\text { governance }\end{array}$ & & & Design Fees \\
\hline $\begin{array}{l}\text { Absorptive } \\
\text { capability }\end{array}$ & $\begin{array}{l}\text { Poor scope } \\
\text { definition }\end{array}$ & & & $\begin{array}{l}\text { Planning During } \\
\text { Design }\end{array}$ \\
\hline $\begin{array}{l}\text { Personal } \\
\text { relationship }\end{array}$ & $\begin{array}{l}\text { Traditional } \\
\text { procurement }\end{array}$ & & & \\
\hline $\begin{array}{l}\text { Learning } \\
\text { equilibrium }\end{array}$ & $\begin{array}{l}\text { Competitive } \\
\text { tendering }\end{array}$ & & & \\
\hline \multirow[t]{2}{*}{$\begin{array}{l}\text { Client and End- } \\
\text { User } \\
\text { Requirements }\end{array}$} & $\begin{array}{l}\text { Poor design } \\
\text { integration }\end{array}$ & & & \\
\hline & $\begin{array}{l}\text { Design Checks, } \\
\text { Audits, and } \\
\text { Reviews }\end{array}$ & & & \\
\hline
\end{tabular}

\section{REFERENCES}

[1] D. Kumaragamage, "Design Manual," 2011.

[2] PMI (Project Management Institute), "PMBOK Guide 5th Edition," 2013.

[3] F. Chalabi, G. A., F. Salazar, and B. J. Beaudin, "Defining and Evaluating Input Variables Impacting Design Effectiveness Research Phase I," Worcester, 1986.

[4] G. N. Suther, "Evaluating The Perception of Design Erros in The Costruction Industry," Florida, 1998.

[5] D. Kaminetzky, Design and Construction Failures: Lessons from Forensic. New York: McGraw-Hill, 1991.

[6] Han, S., Love, P., \& Peña-Mora, F. (2013). A system dynamics model for assessing the impacts of design errors in construction projects. Mathematical and Computer Modelling, vol 57, no -, page 2044-2053.

[7] Walker, D. H. (2009). Exploratory factors influencing design practice learning within a Thai context. Engineering, Construction and Architectural Management, vol 16, no 3 , page 238-253.

[8] Love, P. E., Lopez, R., Edwards, D. J., \& Goh, Y. M. (2012). Error begat error: Design error analysis and prevention in social infrastructure projects. Accident Analysis and Prevention, vol 48,no -, page 100-110.

[9] Lopez, R., Love, P. E., Edwards, D. J., \& Davis, P. R. (2010). Design Error Classification, Causation, and Prevention in Construction Engineering. Journal of Performance of Constructed Facilities, vol 24, no 4, page 399-408.

[10] Hurst, N. W., Bellamy, L. J., Geyer, T. A., \& Astley, J. A. (1991). A classification scheme for pipework failures to include human and sosiotechnical errors and their contribution to pipework failure frequencies. Journal of Hazardous Materials, vol 26, hal 159-186.

[11] Robson, C. (2002) Real World Research (2nd edn). Oxford: Blackwell..

[12] Love, P. E., Edwards, D. J., \& Irani, Z. (2008). Forensic Project Management: An Exploratory Examination of the
Causal Behavior of Design-Induced Rework. IEEE Transactions On Engineering Management, vol 55, no 2, page 234-247.

[13] http://dinus.ac.id/repository/docs/ajar/mandes_2.pdf. (n.d.). Universitas Dian Nuswantoro. Retrieved 2017

[14] Szalapaj, P. (2005). Contemporary Architecture and the Digital Design Process. Oxford: Elsevier.

[15] Rahmawati, Y., Utomo, C., Anwar, N., Negoro. N.P., and Nurcahyo, C.B. (2014), "A Framework of Knowledge Management for Successful Group Decision”, IEEE Conference on Open System, Subang Jaya, Malaysia, October 27

[16] Y. Rahmawati, and C. Utomo. (2014). "The Influence of Knowledge Management to Integrated Design", 1s International Conference on Information Technology, Computer, and Electrical Engineering (ICITACEE), pp. 193-198, November.

[17] C. Utomo, R.M. Zin, R. Zakaria, and Y. Rahmawati. (2014) "A Conceptual Model of Agreement Options for Valuebased Group Decision on Value Management", Jurnal Teknologi, vol. 70 (7), pp. 39-45.

[18] Rahmawati, Y., Utomo, C., dan Anwar, N. (2013), "The Role of Knowledge Management in Collaborative Design to Support Construction Process", 13th Internationa Conference on Quality in Research, Yogyakarta, 25-28 Juni.

[19] Y. Rahmawati, C. Utomo, N. Anwar, C.B. Nurcahyo, and N.P. Negoro, (2014). "Theoretical Framework of Collaborative Design Issues", Jurnal Teknologi, vol. 70 (7), pp. 47-53.

[20] Y. Rahmawati, C. Utomo, N. Anwar, P. Setijanti, and C.B Nurcahyo (2014).“An Empirical Model for Successful Collaborative Design towards Sustainable Project Development", Journal of Sustainable Development, vol. $7(2)$, pp. 1-14.

[21] Utomo, C., dan Rahmawati, Y., (2012), "The Achievement to Sustainability on Vertical Housing Development through Whole System Design", 3rd International Seminar on Tropical Eco Settlements, Jakarta, 31 Oktober 